\title{
Review
}

\section{Metabolic Profile Characterization of Different Thyroid Nodules Using FTIR Spectroscopy: A Review}

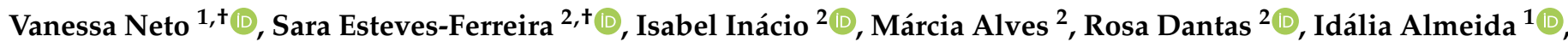 \\ Joana Guimarães ${ }^{2}$, Teresa Azevedo ${ }^{2}$ and Alexandra Nunes $1, *$ (D) \\ 1 Department of Medical Sciences, iBiMED-Institute of Biomedicine, University of Aveiro, \\ 3810-193 Aveiro, Portugal; vanessaneto98@ua.pt (V.N.); idalia24@ua.pt (I.A.) \\ 2 Centro Hospitalar do Baixo Vouga, CHBV-Endocrinology Department, 3810-164 Aveiro, Portugal; \\ saragabrielaferreira@gmail.com (S.E.-F.); isabelmrinacio@gmail.com (I.I.); \\ Marcia.Ines.alves@gmail.com (M.A.); rdantas84@gmail.com (R.D.); Joanaguimaraes.endoc@gmail.com (J.G.); \\ tcmfazevedo@gmail.com (T.A.) \\ * Correspondence: alexandranunes@ua.pt \\ + These authors contributed equally to this work.
}

check for updates

Citation: Neto, V.; Esteves-Ferreira, S.; Inácio, I.; Alves, M.; Dantas, R.; Almeida, I.; Guimarães, J.; Azevedo, T.; Nunes, A. Metabolic Profile Characterization of Different Thyroid Nodules Using FTIR Spectroscopy: A Review. Metabolites 2022, 12, 53. https://doi.org/10.3390/ metabo12010053

Academic Editor: Helen G. Gika

Received: 30 November 2021

Accepted: 5 January 2022

Published: 8 January 2022

Publisher's Note: MDPI stays neutral with regard to jurisdictional claims in published maps and institutional affiliations.

Copyright: (C) 2022 by the authors. Licensee MDPI, Basel, Switzerland. This article is an open access article distributed under the terms and conditions of the Creative Commons Attribution (CC BY) license (https:// creativecommons.org/licenses/by/ $4.0 /)$.

\begin{abstract}
Thyroid cancer's incidence has increased in the last decades, and its diagnosis can be a challenge. Further and complementary testing based in biochemical alterations may be important to correctly identify thyroid cancer and prevent unnecessary surgery. Fourier-transform infrared (FTIR) spectroscopy is a metabolomic technique that has already shown promising results in cancer metabolome analysis of neoplastic thyroid tissue, in the identification and classification of prostate tumor tissues and of breast carcinoma, among others. This work aims to gather and discuss published information on the ability of FTIR spectroscopy to be used in metabolomic studies of the thyroid, including discriminating between benign and malignant thyroid samples and grading and classifying different types of thyroid tumors.
\end{abstract}

Keywords: nodular thyroid pathology; thyroid cancer; thyroid tissue; thyroid cytology; metabolome; Fourier-transform infrared spectroscopy; multivariate analysis

\section{Introduction}

Thyroid cancer's incidence has spiked in the last decades, although still maintaining an overall good prognosis [1]. However, its diagnosis can pose a challenge since it is difficult to differentiate a malignant nodule from a benign one [2,3]. Cytological analysis of fine needle aspiration (FNA) samples provides an estimated risk of malignancy, but definite diagnosis requires histological analysis, which has to be obtained through surgical resection. Thyroid surgery carries the risk for uncommon but significant complications, such as hypoparathyroidism or vocal cord paralysis. Only $20 \%$ of cytologically indeterminate nodules prove to be malignant, meaning a proportion of patients are subject to diagnostic rather than curative thyroidectomy. Therefore, further and complementary testing based in biochemical alterations may be important to correctly identify thyroid cancer and prevent unnecessary surgery. Since biochemical alterations precede morphological changes in cells, the cancer metabolome has gained relevance and may contribute to understand tumor biology and to identify early diagnostic biomarkers. Fourier-transform infrared (FTIR) spectroscopy is a metabolomic technique that, unlike histopathologic approaches, is rapid, low cost and uses a small amount of sample. This technique gives information on the biochemical composition of samples and allows the discrimination of samples with different metabolic profiles, being able to discriminate cancerous and non-cancerous samples. Spectral analysis is possible with multivariate analysis (MVA), which allows to identify groups of molecules that may act as potential biomarkers of cancer. FTIR has already shown promising results in cancer metabolome analysis of tissues, in the 
identification and classification of prostate tumor tissues and of breast carcinoma, and was also used in metabolomic studies of thyroid, enabling the discrimination between benign and malignant thyroid samples and grading and classifying different types of thyroid tumors. This works aims to gather the published data on the application of FTIR in the metabolome of the thyroid gland.

\section{Thyroid Gland}

The thyroid is an endocrine gland located in the lower anterior neck. Its main function is to secrete triiodothyronine (T3) and thyroxine (T4), hormones produced from the iodine obtained from a diet [4]. Thyroid function is regulated by the hypothalamic-pituitary-thyroid (HPT) axis. The hypothalamus produces thyrotropin-releasing hormone (TRH), which stimulates the pituitary gland to secrete thyroid-stimulating hormone (TSH), or thyrotropin. This hormone acts on the thyroid, stimulating cell growth and hormone production. Thyroid hormones, in turn, exert negative feedback on the hypothalamus and pituitary, inhibiting the secretion of TRH and TSH, in such a manner that the hormone levels are maintained within a narrow range [5].

\section{Nodular Thyroid Pathology}

Thyroid disorders are extremely common, making thyroid diseases one of the most common subtypes of endocrine disorders worldwide [6,7]. They can be divided into two independent entities: functional and structural disorders. Thyroid structural pathology is comprised mostly of nodular disease.

\subsection{Epidemiology and Etiology}

Thyroid nodules consist of lesions within the thyroid gland that are radiologically distinct from the surrounding thyroid parenchyma. These represent a common clinical entity, with up to $68 \%$ of the population having ultrasound-detectable nodules and higher rates being observed in women and the elderly [8]. In about half of the patients, the nodules are solitary [9]. Multinodularity (more than one node) increases with age, body mass index and female sex $[10,11]$. Even though they are prevalent, approximately $90 \%$ are asymptomatic [8]. The clinical relevance of thyroid nodules relates to the risk of thyroid dysfunction (5\%), compressive symptoms (5\%) or thyroid cancer (which occurs in about $10 \%$ ) [12]. Some factors may contribute to a higher risk of malignancy, such as age, male sex, radiation exposure history in childhood or adolescence, family history of thyroid cancer or hereditary syndromes that include thyroid cancer (such as multiple endocrine neoplasia syndrome type 2 or familial adenomatous polyposis), rapid nodule growth or hoarseness [8,12]. Other risk factors were proposed, such as serum thyrotropin levels, thyroid antibodies, obesity and metabolic syndrome, but the evidence available at the moment is insufficient [13-17].

Functional thyroid disease occurs when there is either an under or overproduction of thyroid hormones, corresponding to a clinical state of hypothyroidism or hyperthyroidism, respectively [18]. This can be evaluated through measurement of serum T3, T4 and TSH. Thyroid nodules can occur with hypothyroidism, hyperthyroidism or euthyroidism. The function of the nodules can be independent from regulation from the HPT axis, meaning that the nodules can function differently from the remaining parenchyma. Hypofunctioning or "cold" nodules do not produce thyroid hormones, while hyperfunctioning or "hot" nodules synthesize hormones autonomously, without the need of stimulation from TSH, often resulting in hyperthyroidism.

\subsection{Management and Prognosis}

The main goal of thyroid nodules management is to identify the nodules at greater risk of malignancy, allowing for timely and effective treatment in order to prevent cancer-related morbidity and mortality, while preventing invasive procedures from being performed on benign or low risk pathology. More than $90 \%$ of thyroid nodules are benign and do not 
require immediate therapeutic intervention, only monitoring $[9,19,20]$. These nodules are rarely of clinical significance, except for very large nodules that result in compressive symptoms (from airway and/or digestive tract obstruction) or in hyperfunctioning nodules, which cause hyperthyroidism.

The vast majority of thyroid cancers (95\%) correspond to differentiated thyroid cancer (DTC) that originated from thyroid follicular epithelial cells. The most common form of DTC, corresponding to $85 \%$ of patients, is papillary thyroid carcinoma, which carries the best overall prognosis. Follicular thyroid carcinoma accounts for $12 \%$ of DTC and poorly differentiated and anaplastic thyroid carcinomas, two entities associated with a worse prognosis, are much less frequent ( $<3 \%$ of DTC and $<1 \%$ of thyroid cancers, respectively) $[17,21,22]$.

Classically, surgical resection is the mainstay of thyroid cancer treatment-either lobectomy or total thyroidectomy, with or without lymph node dissection, according to preoperative staging [8]. Despite advances in surgical techniques aiming to minimize the occurrence of adverse effects, thyroid surgery still carries risks [23]. These include transient $(1.2 \%)$ or permanent $(0.6 \%)$ vocal cord palsy and transient $(27.5 \%)$ or permanent $(7.1 \%)$ hypoparathyroidism [24]. Complication rates are lower for surgeries performed by an experienced surgeon [23]. Besides these complications, permanent iatrogenic hypothyroidism, with need for lifelong supplementation with levothyroxine, occurs in all patients subject to total thyroidectomy and about $22 \%$ of patients following hemithyroidectomy [25].

Morbimortality associated with thyroid cancer derives mostly from complications of extrathyroidal extension, which occurs in $10-15 \%$ of patients, with invasion of adjacent structures or distant metastasis [17]. Locally advanced disease most commonly involves the strap muscles (53\%), recurrent laryngeal nerve $(47 \%)$, trachea (37\%), esophagus $(21 \%)$ and larynx (12\%) [26]. The most frequent symptoms are dysphonia, dysphagia, dyspnea, coughing, bleeding, vocal cord paralysis, upper airway obstruction and cervical pain $[27,28]$. The most frequent sites of distant metastization are the lungs $(75 \%)$, bone $(45 \%)$ and brain $(6.8 \%)$, with $25 \%$ of patients presenting with more than one affected organ [29]. However, it is still an entity with a predominantly good prognosis, with a 5-year survival rate of $98.3 \%$ overall and $99.9 \%$ in localized disease, making it the cancer with the highest relative survival rate in the USA between 2011 and 2017 [30].

\subsection{Diagnosis}

The more widespread use of imaging techniques and FNA biopsies resulted in a significant rise in the incidence of thyroid cancer, with a three-fold increase from 1975 to 2009. However, this has not resulted in an improvement in mortality rates, which remained relatively stable at 0.5 deaths per 100,000 [31]. The most likely explanation rests on the fact that most of the increment in incidence was a result of an increased diagnosis of small papillary carcinomas, which have been shown to be of very good prognosis and therefore are unlikely to lead to clinically apparent disease [32-34]. A study of thyroid cancer incidence trends estimated that over 830,000 women and 220,000 men might have been overdiagnosed between 2008 and 2012 in the 26 countries analyzed [35]. Besides direct complications from overtreatment, overdiagnosis leads to financial costs and an increased burden for health systems and for patients, with thyroid cancer survivors showing lower health-related quality of life and higher levels of anxiety, despite their good prognosis [35,36]. This knowledge has led to a recent trend towards a less invasive approach, in order to avoid complications of overdiagnosis and overtreatment of an otherwise indolent disease.

Since the majority of patients with thyroid nodular lesions are asymptomatic, the diagnosis is often accidental $[27,28,37]$. In the presence of a suspected or confirmed thyroid nodule, an ultrasound should be performed. Besides evaluating the presence of nodules, the sonographic features and size confer to a nodule a risk of malignancy, which is in turn used to guide FNA decision-making. Sonographic features associated with a higher risk of malignancy include the presence of microcalcifications, hypoechogenicity, irregular margins and a shape taller than wide measured on a transverse view [8]. Other 
ultrasound findings should be taken into account, such as the presence of suspicious lymphadenopathy, extrathyroidal extension, vascularity and a thick or absent halo [38]. Different recommendations have been issued by various scientific societies regarding indications for FNA $[17,38,39]$. Besides sonographic features, thyroid function should also be considered before FNA is performed. For patients with hyperthyroidism, a radionuclide thyroid scan, a functional study of the gland, should be obtained to assess whether the nodule is hyperfunctioning. Since these nodules are rarely malignant, cytologic evaluation can be dismissed [8].

The FNA specimens are then subject to cytopathological examination and its results are reported according to the Bethesda system. They are classified into one of six categories: I. Nondiagnostic or unsatisfactory; II. Benign; III. Atypia of undetermined significance or Follicular lesion of undetermined significance (FLUS); IV. Follicular neoplasm or Suspicious for a follicular neoplasm; V: Suspicious for malignancy; VI. Malignant. Again, an estimated risk of malignancy is attributed to each category, on which future treatment or follow-up decisions should be based. Definitive diagnosis of either benignity or malignancy can only be established through histological analysis, which requires that a surgical resection of the thyroid is performed. Nodules with a Bethesda II cytology have a low risk of malignancy, so no further immediate studies or treatment are required. Follow-up should be maintained according to sonographic features. For nodules within the Bethesda IV, V and VI categories, surgery is generally recommended, given the high risk of malignancy. For nodules with a non-diagnostic (Bethesda I) or FLUS (Bethesda III), repeat cytology should be considered. Nevertheless, in case of repeated results, in the presence of suspicious sonographic features or according to patient preference, surgery can be considered over ecographic monitoring [17]. However, only about $20 \%$ of indeterminate thyroid nodules (Bethesda III and IV) have proven to be malignant at final histology, meaning a significant proportion of patients are subject to a diagnostic rather than curative thyroidectomy [40]. With the intent of avoiding that phenomenon, multiple strategies have been proposed to enhance FNA cytology diagnostic performance, such as molecular testing [41].

\section{New Diagnostic Approach-Metabolomics Techniques}

Another promising approach includes "omics" techniques, which are used to accurately identify thyroid pathologies based on biochemical changes, with impact in the patients' quality of life and in the efficiency of health services [42,43]. The "omics" field encompasses multiple approaches such as genomics, transcriptomics, proteomics, lipidomics and metabolomics. The latter is a vast, promising emerging field, since it allows the study of the complete set of biomolecules/metabolites that make up a biological sample, whether it is under physiologically or biochemically altered conditions due to the occurrence of diseases, such as cancer, or physiological processes, such as aging [44,45].

This study of small molecules can be applied in biological studies that use either tissues (e.g., ex-vivo samples, as biopsies) or in peripheral fluids (e.g., plasma, serum, urine, saliva), and can also be used in other in vitro studies, using cell line models [46].

Cancer is a pathology that is differentiated, especially by the manifestation of several cellular and molecular modifications, modifications that result in an altered metabolism in comparison with normal cells [43]. In this way, cancer cells manifest a unique and distinct metabolic phenotype [44]. Since biochemical alterations precede morphological changes in cells, the cancer metabolome, which represents the most "downstream" level of molecular life of a cell, has gained relevance and may contribute to identify early diagnostic and prognostic biomarkers to be applied in clinical practice. In addition to allowing the discovery of novel markers, the study of the thyroid cancer metabolome also enables an understanding of tumor biology through the study of the molecular pathways responsible for the process of carcinogenesis. Thus, the metabolome reflects the molecular and phenotypic state of an organism, both physiologically and pathologically, so the determination of metabolites in altered cancer cells seems to be a promising approach for its study [43,44]. Although this metabolomics approach is still not used routinely in clinics 
and pre-clinics, it allows to identify small molecules and, consequently, the phenotypic characteristics of cancer cells, as well as presents a series of characteristics that make it an excellent option, such as a quick, specific, sensitive and reproducible diagnostic analysis [47].

There are many studies in which the successful application of genomic [48,49], proteomic $[50,51]$ and transcriptomic $[49,52]$ techniques is evidenced in the area of thyroid cancer; however, the same situation does not apply to the application of metabolomics. Nevertheless, over the past few years, the metabolomics approach in terms of thyroid diagnosis has shown an enormous evolution, which is due, in part, to the application of several analytical techniques that allow the study of the complete set of small biomolecules that make up a biological sample. The main metabolomics techniques that have mostly been adopted in the thyroid, in an attempt to identify biomarkers, classify the thyroid cancer, facilitate an earlier diagnosis and prevent the development and invasion at the systemic level of the cancer itself, are Mass Spectrometry (MS) [53-55], Nuclear Magnetic Resonance (NMR) [53,56,57], Raman Spectroscopy [58-60] and Fourier Transform Infrared (FTIR) Spectroscopy [61-79]. This increase in the number of studies is attributed to the greater availability of improved and accurate metabolomics techniques that exist and also due to the development of appropriate statistical tools that are able to handle the huge amount of data resulting from the samples under analysis [80].

All of these metabolomics techniques, in general, present high sensitivity, specificity and precision with respect to the identification and often to the absolute determination of the concentration of the multiple metabolites that constitute the complex biological samples under analysis. In addition, these techniques also stand out for the fact that they are potentially non-invasive (in a biological fluid-based experimental design), have a highthroughput, are highly reproducible, non-destructive (some experiments use the sample without pre-processing, and thus do not cause any alteration/destruction of the sample that remains intact) and also allow the analysis of both solid samples (e.g., tissues) as well as liquids (e.g., cytologies or plasma) $[43,53,81]$. Thus, when these techniques are applied and analyzed correctly, clinically it is possible to obtain a reliable and an accurate result in relation to the identified thyroid pathology. However, there is an enormous complexity associated with the physiology and pathophysiology of the thyroid, as well as a great complexity and uncertainty, sometimes felt in relation to the metabolomics methods of diagnosis. This can result in the inappropriate use of these methods, culminating in an expensive (use of very expensive technical equipment) and, sometimes, time-consuming (slower sample processing) diagnosis [43,82].

\section{FTIR Spectroscopy and Thyroid Cancer}

FTIR Spectroscopy is a metabolomic technique that can be used as a diagnostic method in the area of cancer. In addition to what was mentioned above about the other metabolomic techniques, FTIR spectroscopy is still characterized as being reagent-free (does not require any biochemical reagents), quite simple (can be performed by any clinician or technician with only a minimal training), fast (it only takes $15 \mathrm{~min}$ to perform) and objective (allows a reduction in the mistakes made by human subjective judgment), which requires little or no sample preparation, requires a small amount of sample (leaves sufficient material for other clinical tests) and that has proven to be a cost-effective technique whose application can be extended to clinical diagnosis $[62,67,68]$. It is also a very innovative method that allows the screening of the metabolic profile of each analyzed sample and, consequently, to trace its spectroscopic profile. The IR spectrum, obtained through FTIR analysis, can serve as a spectroscopic signature that allows the characterization of several pathologies depending on their metabolic profile [47]. Despite this huge set of advantages, FTIR presents a major disadvantage or limitation that is based on the intense absorption of water in the mid-IR region of the electromagnetic spectrum, masking the vibrational absorption of the other biomolecules, this is a limiting situation due to the fact that all biological samples (tissues, cells and body fluids) that can be analyzed are mostly made up of water [83]. However, this 
situation can be easily overcome by three different strategies, namely, by subtracting the water absorption signal, by dehydrating the sample or letting the sample dry directly on the crystal when attenuated total reflectance (ATR) is used as a sampling method $[47,84]$.

Some research groups have already shown promising results in which the high sensitivity of this spectroscopic method was detected in the identification and discrimination of various types of cancer at the level of the spectroscopic analysis of tissue samples from organs such as the lungs [85], breast [86] and prostate [87,88]. In fluid analysis, FTIR has been used in the study of the metabolome associated with physiological alterations, revealing a huge potential in the early and minimally invasive diagnosis of several pathologies $[89,90]$. In fact, FTIR spectroscopy is a promising metabolomic analytical technique; it is a type of vibrational spectroscopy that is based on the vibration of the atoms in a molecule [47]. This technique makes it possible to detect the biochemical composition of a biological sample in relation to the different macromolecules that constitute it, such as nucleic acids, carbohydrates, lipids and proteins, by enabling the identification of functional groups, molecular conformations, types of connection and the different intermolecular interactions that make up the sample. It is then possible to use this technique to study the composition of more complex biological samples such as cells, tissues and body fluids [91]. Each chemical or biochemical sample has its own infrared spectrum which is reflected in the existence of a unique infrared fingerprint attributed to each analyzed substance. Thus, each change that occurs in the biomolecules, resulting from the process of carcinogenesis, for example, results in the modification of this "fingerprint" and, consequently, allows the distinction between normal cells and altered cancer cells [47,91].

According to the inclusion criteria defined for the construction of Table 1, less than 20 papers were found in the last 20 years. These studies include both thyroid tissue and cytology samples. The small number of existing papers may be related to the fact that cytological samples are difficult to collect, due to the invasive nature of the FNA procedure, and to the small amount of sample obtained within this process. However, though more challenging, the use of cytology samples, in our opinion, is more advantageous, since their analysis, realized prior to surgery, may contribute to avoid thyroid excision in patients with an unprecise diagnosis.

Table 1. Summary of the FTIR spectroscopy research studies in the characterization of normal and cancerous thyroid samples, highlighting the sample and analysis types, acquisition parameters and the principal findings of each study. Search for studies performed on 22 December 2021, on PubMed, under the following terms: ("Thyroid Gland"[MAJR]) AND ("Spectroscopy, Fourier Transform Infrared"[MeSH]); and on ScienceDirect, under the following terms: (Infrared Spectroscopy AND Thyroid tumor AND FNA cytology). The results were manually filtered to ensure that they all reported studies that use FTIR spectroscopy in the analysis of normal and nodular thyroid samples. Articles in Chinese and academic research documents were excluded from the table. The sequence of the articles in the table follows a chronological order. ( $\uparrow$ increase; $\downarrow$ decrease).

\begin{tabular}{|c|c|c|c|c|c|}
\hline Sample Type & Acquisition Conditions & Analysis Type & & Main Findings & References \\
\hline $\begin{array}{l}\text { FNA citology (original aspirate; } \\
\text { cell-free supernant; cell pellet) }\end{array}$ & $\begin{array}{c}\mu-\mathrm{FTIR} \\
\text { Scans: } 256 \\
\text { Resolution: } 4 \mathrm{~cm}^{-1} \\
\text { Spectral region: } 1200-900 \mathrm{~cm}^{-1}\end{array}$ & \multirow{3}{*}{$\begin{array}{l}\text { Unsupervised Cluster } \\
\text { analysis (Ward's minimum } \\
\text { variance algorithm and } \\
\text { Euclidian distances) and } \\
\text { Bivariate statistical analysis; }\end{array}$} & - & $\begin{array}{l}\text { NG spectra: strong protein ( } 1545 \text { and } \\
\left.1655 \mathrm{~cm}^{-1}\right) \text { and carboxylate bands } \\
\left(1409 \text { and } 1578 \mathrm{~cm}^{-1}\right) \text {; } \\
\text { Typical follicle characteristic spectra: }\end{array}$ & \multirow{3}{*}{ [75] } \\
\hline \multirow[t]{2}{*}{ Tissue from thyroid gland } & $\begin{array}{c}\mu-F T I R \\
\text { Scans: } 16\end{array}$ & & - & $\begin{array}{l}\text { Typical follicle characteristic spectra: } \\
\text { - colloid: } \alpha \text {-helical protein pro- } \\
\text { file of thyroglobulin; } \\
\text { epithelium: DNA }\left(968 \mathrm{~cm}^{-1}\right) \text {, } \\
\text { collagen }\left(1338 \quad \mathrm{~cm}^{-1}\right) \text { and } \\
\text { lipids }\left(1740 \mathrm{~cm}^{-1}\right) ;\end{array}$ & \\
\hline & & & & $\begin{array}{l}\text { Neoplastic tissues: } \uparrow \text { DNA } \downarrow \text { Protein } \\
\text { (except: PTC that } \uparrow \text { Protein); }\end{array}$ & \\
\hline
\end{tabular}


Table 1. Cont.

\begin{tabular}{|c|c|c|c|c|}
\hline Sample Type & Acquisition Conditions & Analysis Type & Main Findings & References \\
\hline $\begin{array}{c}n=89 \\
\text { FNA citology samples of } 89 \\
\text { thyroid nodules (original aspirate; } \\
\text { cell pellet) } \\
\text { Thyroid powder }\end{array}$ & $\begin{array}{c}\text { Transmission } \\
\text { Resolution: } 4 \mathrm{~cm}^{-1} \\
\text { Spectral region: } 1800-900 \mathrm{~cm}^{-1}\end{array}$ & $\begin{array}{l}\text { Baseline correction, area } \\
\text { normalization and second } \\
\text { derivatives using the } \\
\text { Savitzky-Golay algorithm; } \\
\text { Unsupervised Cluster analysis } \\
\text { (Ward's minimum variance } \\
\text { algorithm and Euclidian } \\
\text { distances) and Supervised } \\
\text { Linear discriminant analysis; }\end{array}$ & $\begin{array}{l}\text { - The most prominent bands are protein } \\
\text { absorptions }\left(1652 \text { and } 1542 \mathrm{~cm}^{-1}\right) ; \\
\text { - } \\
\text { Thyroid powder: high DNA content } \\
\left(966,1087,1240 \text { and } 1713 \mathrm{~cm}^{-1}\right) ; \\
\text { - Cell pellets - more content of lipids } \\
\left(1740 \mathrm{~cm}^{-1}\right) ; \\
\text { Thyroglobulin and FNA aspirate - } \\
\text { characteristic carbohydrate bands } \\
\left(1000-1190 \mathrm{~cm}^{-1}\right) \text { and also two strong } \\
\text { protein bands }\left(1545 \text { and } 1655 \mathrm{~cm}^{-1}\right) ; \\
\text { Tumor group - prominent carboxy- } \\
\text { late }\left(1409 \text { and } 1580 \mathrm{~cm}^{-1}\right) \text {, lipid es- } \\
\text { ter }\left(1740 \mathrm{~cm}^{-1}\right) \text { and carbohydrate bands } \\
\left(950-1200 \mathrm{~cm}^{-1}\right) ;\end{array}$ & [62] \\
\hline $\begin{array}{c}n=184 \\
\text { Cervical lymph nodes } \\
\text { (61 metastatic; } 123 \text { non-metastatic) } \\
\text { from } 22 \text { PTC patients }\end{array}$ & $\begin{array}{c}\text { ATR } \\
\text { Scans: } 32 \\
\text { Resolution: } 8 \mathrm{~cm}^{-1} \\
\text { Spectral region: } 4000-1000 \mathrm{~cm}^{-1}\end{array}$ & $\begin{array}{l}\text { Intensity measurement of } \\
\text { spectroscopic signals with } \\
\text { relative intensity ratios; } \\
\text { Wilks' lambda linear } \\
\text { discriminant analysis; }\end{array}$ & 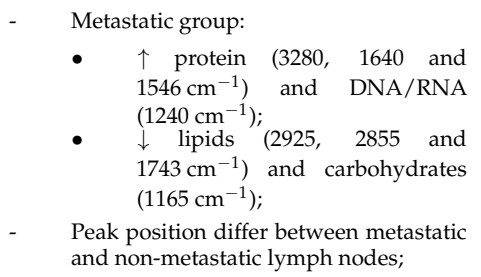 & [67] \\
\hline $\begin{array}{c}n=60 \\
60 \text { Thyroid gland tissue samples } \\
\text { (43 of NG; } 17 \text { of PTC) }\end{array}$ & $\begin{array}{c}\text { ATR } \\
\text { Scans: } 32 \\
\text { Resolution: } 4 \mathrm{~cm}^{-1} \\
\text { Spectral region: } 4000-800 \mathrm{~cm}^{-1}\end{array}$ & $\begin{array}{l}\text { Baseline correction, straight-line } \\
\text { generated and smoothed; } \\
\text { Measured the wave intensity } \\
\text { ratios and the peak positions; } \\
\text { canonical discriminant analysis }\end{array}$ & $\begin{array}{l}\text { - Differences between the spectroscopic } \\
\text { profile of benign and malignant groups; } \\
\text { Main differences between PTC and NG } \\
\text { groups: } \\
\text { - peak positions: P1640 (amide I), } \\
\text { P1240 (P = O stretch), P1550 } \\
\text { (amide II); } \\
\text { peak intensity ratios: } 3375 / 1460, \\
\text { I1640/1460, 1400/1460, } \\
\text { 1550/1080, 1080/I1460, and } \\
1640 / 1550 ;\end{array}$ & [68] \\
\hline
\end{tabular}

3 spectra: peaks at 916, 1630 and $1460 \mathrm{~cm}^{-1}$;

T4 spectra: peaks at 1190,1476 and $1468 \mathrm{~cm}^{-1}$;

Vector normalization, converted to second derivatives using the

$$
n=80
$$

\[ n=80 \]
80 Thyroid gland tissue samples

T3 and T4 Thyroid hormones
$\mu$-FTIR

Resolution: $4 \mathrm{~cm}^{-1}$ Spectral region: $4000-750 \mathrm{~cm}^{-1}$ Savitzky-Golay algorithm, noise-filtered and phase corrected

Hierarchical cluster analysis (Ward's minimum variance algorithm and Euclidian distances);

Peak at $1468 \mathrm{~cm}^{-1}$ (amount of DIT) and at $1460 \mathrm{~cm}^{-1}$ (amount of MIT) found in all spectrums of normal thyroid tissues but showed differences in their intensity profiles:

Iodinated thyroglobulin: $\alpha$-helix structure Non-iodinated thyroglobulin: $\beta$-sheet structure; Baseline correction and a smoothing with a 9-point moving average;

$n=161$
161 subjects ( 25 males; 136 females)-111 patients undergoing thyroid surgery

50 healthy volunteers

\section{ATR using optical fiber trough skin surface}

Scans: 32
Resolution: $8 \mathrm{~cm}-1$ Spectral region: $3100-1000 \mathrm{~cm}^{-1}$
Intensity measurement of spectroscopic signals with relative intensity ratios; relative intensity ratios;
Wilks' lambda stepwise Wilks' lambda stepwise
discriminant analysis
Normal control group successfully dicriminated from NG and PTC groups (High discriminant accuracy $(88,8 \%)$; Potential to noninvasively discriminate thyroid nodules (NGs and PTCs) from normal controls;

Difficult to discriminate NG from PTC group;

In cancer groups: $\downarrow$ relative intensity ratios for carbohydrates and lipids;
Baseline correction; Normalization of average spectra to the absorbance of

$1651 \mathrm{~cm}^{-1}$;
Principle component analysis $n=20$ (10 of FvPTC; 10 of FTC) Scans: 8
Resolution: $4 \mathrm{~cm}^{-1}$

\section{$\mu$-FTIR
Scans: 8} Spectral region: $3850-900 \mathrm{~cm}^{-1}$ and Linear discriminant analysis; $n=112$
112 Thyroid gland tissue samples (67 of NG; 10 of thyroid carcinomas)

\section{ATR
Scans: 32}

Resolution: $8 \mathrm{~cm}^{-1}$ Spectral region: $1900-1050 \mathrm{~cm}^{-1}$
Intensity measurement of spectroscopic signals with relative intensity ratios; Tests of normal distribution and variance of homogeneity and Student's $t$ test
Spectral analysis of follicular cells discrimination between FvPTC and FTC; It wasn't possible to discriminate FvPTC from FTC;

Significant differences between spectra of NG and thyroid carcinomas in almost all peaks (except protein peaks); 
Table 1. Cont.

\begin{tabular}{|c|c|c|c|c|}
\hline Sample Type & Acquisition Conditions & Analysis Type & Main Findings & References \\
\hline $\begin{array}{c}n=44 \\
44 \text { Thyroid gland tissue samples } \\
\text { (16 of NG; } 3 \text { of FA; } 4 \text { of thyroiditis; } \\
19 \text { of PTC; } 2 \text { of FTC) }\end{array}$ & Not indicated & $\begin{array}{l}\text { Normalization of the spectra to } \\
\text { the absorbance of } 1651 \mathrm{~cm}^{-1} ; \\
\text { Second derivative; } \\
\text { Determination of bands areas; } \\
\text { Calculation of relative areas } \\
\text { ratio; one-way ANOVA and the } \\
\text { Tukey and Fisher tests }\end{array}$ & $\begin{array}{l}\text { Possible to discriminate between: } \\
\text { benign nodules from healthy } \\
\text { tissues (using spectral region } \\
1345-1482 \mathrm{~cm}^{-1} \text { ); } \\
\text { malignant nodules from healthy } \\
\text { tissues (using mean diameter of } \\
1240 \mathrm{~cm}^{-1} \text { ); }\end{array}$ & [78] \\
\hline $\begin{array}{l}\qquad n=15 \\
\text { Thyroid gland tissue samples of } 15 \\
\text { WI-FTC patients }\end{array}$ & $\begin{array}{c}\text { ATR } \\
\text { Scans: } 64 \\
\text { Resolution: } 2 \mathrm{~cm}^{-1} \\
\text { Spectral region: } 4000-400 \mathrm{~cm}^{-1}\end{array}$ & $\begin{array}{l}\text { Baseline correction (concave } \\
\text { rubberband method), } \\
\text { normalization (min.-max. } \\
\text { method) and second derivative; } \\
\text { Measurement of area under } \\
\text { the curve; } \\
\text { Principle component analysis } \\
\text { and Linear } \\
\text { discriminant analysis; }\end{array}$ & $\begin{array}{l}\text { Main difference between normal and tu- } \\
\text { mor tissue in the protein region (concen- } \\
\text { tration and structure): } \\
\text { - } \quad \beta \text {-sheet in cancerous; } \\
\text { Malignant tissue: values of maximal ab- } \\
\text { sorbance are } \downarrow \text { in all spectra regions; } \\
\text { Neoplastic samples: change in lipid } \\
\text { metabolism; }\end{array}$ & [79] \\
\hline $\begin{array}{c}n=32 \\
32 \text { Thyroid gland tissue samples } \\
\text { (15 FTC patients and } \\
\text { 17 FA patients) }\end{array}$ & $\begin{array}{c}\text { ATR } \\
\text { Scans: } 32 \\
\text { Resolution: } 2 \mathrm{~cm}^{-1} \\
\text { Spectral region: } 1800-800 \mathrm{~cm}^{-1}\end{array}$ & $\begin{array}{c}\text { Baseline correction and } \\
\text { normalization of average spectra } \\
\text { to the intensity sum of all peaks; } \\
\text { Principle component analysis and } \\
\text { Linear discriminant analysis; }\end{array}$ & $\begin{array}{l}\text { Neoplastic tissue spectra }-\downarrow \text { values of } \\
\text { absorbance in protein, nucleic acids and } \\
\text { lipids regions compared with normal } \\
\text { thyroid tissues }(\downarrow \text { is less significant for } \\
\text { FA than for WI-FTC); } \\
\quad \uparrow \text { collagen groups in neoplastic tissues; } \\
-\quad \text { Protein secondary structure: } \\
\text { - } \quad \beta \text {-sheet in cancerous; } \\
\text { - } \quad \alpha \text {-helix in normal tissues; }\end{array}$ & [61] \\
\hline $\begin{array}{l}n=14 \\
14 \text { Thyroid gland tissue samples ( } 3 \text { of } \\
\text { metastatic lymph nodes PTC (PTC }+ \text { ); } \\
6 \text { of non-metastatic lymph nodes } \\
\text { PTC (PTC-); } 5 \text { of normal tissue) }\end{array}$ & $\begin{array}{c}\text { ATR } \\
\text { Scans: } 48 \\
\text { Resolution: } 4 \mathrm{~cm}^{-1} \\
\text { Spectral region: } 4000-600 \mathrm{~cm}^{-1}\end{array}$ & $\begin{array}{l}\text { Baseline correction, vector } \\
\text { normalization, first deivative } \\
\text { and smoothing; } \\
\text { Principle component analysis and } \\
\text { Linear discriminant analysis; } \\
\text { Leave one out cross validation; }\end{array}$ & $\begin{array}{l}\text { Normal group successfully discriminated } \\
\text { from PTC+ and PTC- by intensity differ- } \\
\text { ences of phosphate bands associated with } \\
\text { nucleic acids, proteins and lipids; } \\
\text { PTC+ and PTC- primary tumors are dif- } \\
\text { ferentiated by their nucleic acid, protein } \\
\text { and lipid content; } \\
\text { Clear separation of normal, PTC+ and } \\
\text { PTC- groups through Principle compo- } \\
\text { nent analysis; }\end{array}$ & [69] \\
\hline $\begin{array}{l}n=164 \\
164 \text { Thyroid gland tissue samples } \\
\text { (76 malignant; } 88 \text { benign) }\end{array}$ & $\begin{array}{c}\text { ATR } \\
\text { Scans: } 64 \\
\text { Resolution: } 8 \mathrm{~cm}^{-1} \\
\text { Spectral region: } 4000-1000 \mathrm{~cm}^{-1}\end{array}$ & $\begin{array}{l}\text { Normalization (z-score } \\
\text { normalization) and baseline } \\
\text { correction } \\
\text { (rubberband method); } \\
\text { Principle component analysis } \\
\text { and Linear } \\
\text { discriminant analysis; } \\
\text { Shapiro-Wilk test, tests of } \\
\text { variance of homogeneity and } \\
\text { Mann-Whitney U test; }\end{array}$ & $\begin{array}{l}\text { - Significant differences between spectra } \\
\text { of benign and malignant tissues; } \\
\text { Malignant tissues: } \uparrow \text { absorbances of } \\
\text { peaks attributed to amides and phos- } \\
\text { phorylated proteins; } \\
\text { Benign tissues: } \uparrow \text { absorbances of peaks } \\
\text { related to lipids, nucleic acids, carbohy- } \\
\text { drates and glycogen; } \\
\text { Phosphorylated proteins }\left(878 \mathrm{~cm}^{-1} \text { and }\right. \\
\left.880 \mathrm{~cm}^{-1}\right) \text { are the most dominant } \\
\text { component }(84,65 \% \text { variability among } \\
\text { the samples); }\end{array}$ & [70] \\
\hline
\end{tabular}

Four of the studies from Table 1 used microspectroscopy, a technology not available in all metabolomics laboratories. This approach could be advantageous for the analysis of anatomical pieces, to identify normal and tumor profiles and also to detect the characteristic profiles of the transition region around the tumor. However, studies based on ATR or transmission are quite promising. They require small amounts of sample and are able to accurately discriminate normal from tumor samples.

Regardless the analysis tool and the type of sample used, these metabolomic studies can be an advantage in the quality of life of patients. An accurate analysis of a cytological sample can provide a precise classification result that avoids an unnecessary thyroidectomy. Additionally, metabolic changes precede cytological changes, which allows early identification of a tumor in cytological samples.

In our opinion, before spectroscopy being introduced into clinical practice, and to be used in the diagnosis and classification of thyroid specimens, there is still plenty of work ahead. The dimension of the data sets used needs to be increased. Only four of the studies identified in Table 1 have a number of participants higher than 100. It is essential to have 
large data sets to be able to draw conclusions about the spectroscopic/metabolic profiles of the samples.

In recent years, the number of spectroscopic studies that uses multivariate analysis has been increasing. These tools are essential to analyze larger data sets and to extract relevant and systematic information from spectroscopic data. Only with these statistical tools it will be possible to create classification algorithms that will accurately enable the use of spectroscopy in clinical practice. It is also crucial to use validation data sets to confirm the information obtained by the classification algorithms. Studies that have developed classification algorithms and that use independent data sets to validate the results are uncommon. Therefore, there are still some points to explore in the metabolomic study of thyroid nodules.

The mid-IR region can be divided into four distinct spectra regions, namely, the $\mathrm{X}-\mathrm{H}$ stretching region $\left(4000-2500 \mathrm{~cm}^{-1}\right)$, the triple-bond region $\left(2500-2000 \mathrm{~cm}^{-1}\right)$, the carbonyl (around $1700 \mathrm{~cm}^{-1}$ ) and protein region $\left(1700-1500 \mathrm{~cm}^{-1}\right.$ ) and the fingerprint region $\left(1500-600 \mathrm{~cm}^{-1}\right)$ [92].

Associated with these spectra regions, important with regard to the analysis of biological samples, are the main biomolecules that make up these samples: lipids $\left(3000-2800 \mathrm{~cm}^{-1}\right)$; proteins $\left(1800-1300 \mathrm{~cm}^{-1}\right)$, which can further differentiate into two specific bands, namely, amide I (1700-1600 $\left.\mathrm{cm}^{-1}\right)$, the most used in these analyzes, and amide II $\left(\sim 1540 \mathrm{~cm}^{-1}\right)$, both quite sensitive to the secondary structure of proteins; phospholipids $\left(\sim 1740 \mathrm{~cm}^{-1}\right)$; amino acid side chains and fatty acids $\left(1480-1300 \mathrm{~cm}^{-1}\right)$; and carbohydrates and phosphates associated with nucleic acids $\left(1300-900 \mathrm{~cm}^{-1}\right)$ [93]. Any change that occurs in the frequency (increase or decrease) or in these spectroscopic bands (shape or intensity) may be indicative of cellular changes in the analyzed sample [84,93].

Taking into account all the information mentioned above, a typical IR spectrum of a normal thyroid cytological sample, obtained over the wavenumber $4000-600 \mathrm{~cm}^{-1}$, is presented in Figure 1. The spectral peaks of the typical thyroid cytology and the corresponding biochemical components and vibrational modes are shown in Table 2.

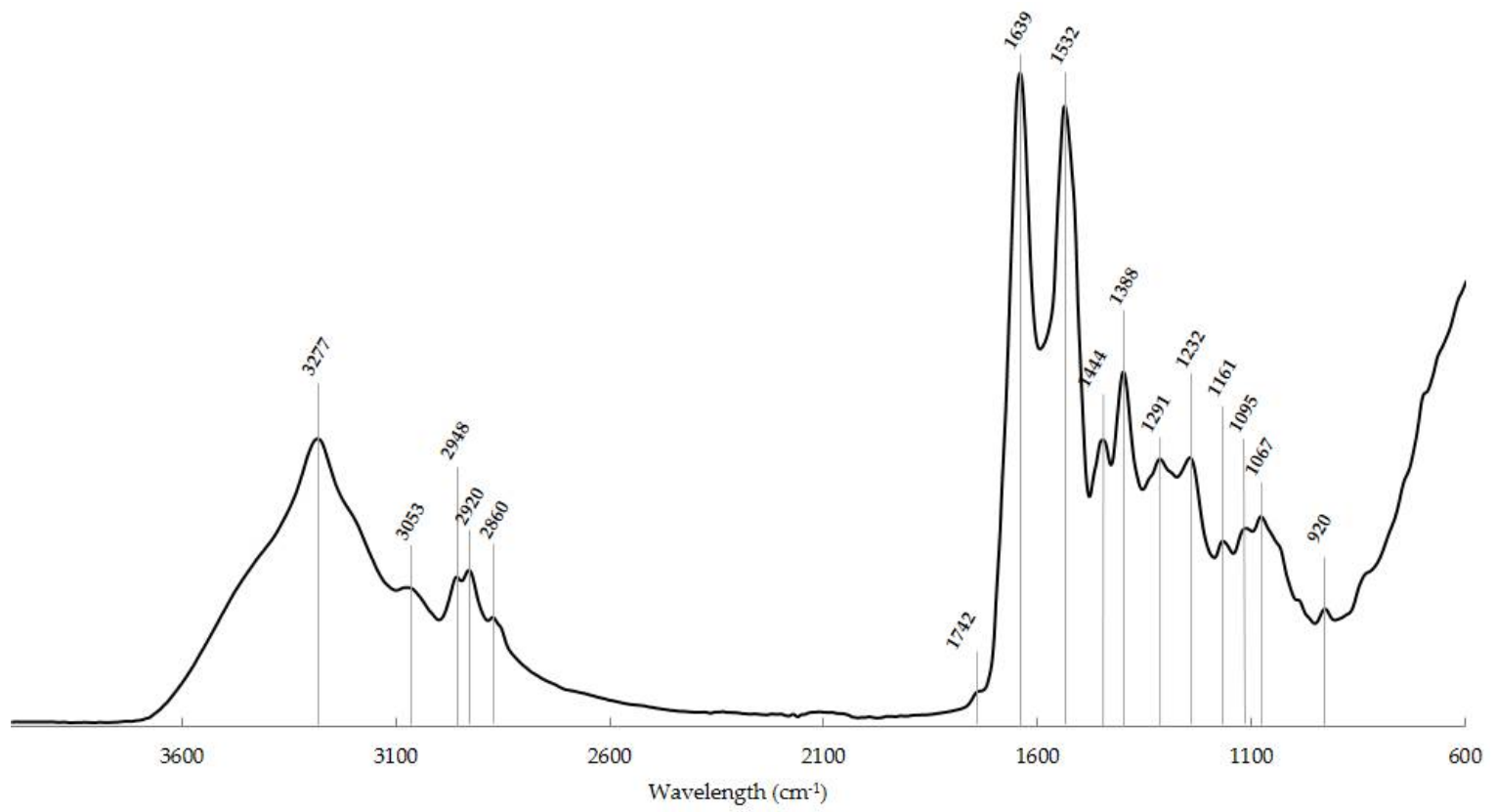

Figure 1. Typical IR spectrum of a normal thyroid cytological sample in the $\sim 4000-600 \mathrm{~cm}^{-1}$ region with the main spectroscopic signals. $x$-axis: wavenumber $\left(\mathrm{cm}^{-1}\right) ; y$-axis: arbitrary units (a.u.). 
Table 2. Spectral peaks and the corresponding biochemical components and vibrational modes of a typical normal thyroid cytological sample obtained by FNA. Adapted from $[47,73,78,86,88,91]$.

\begin{tabular}{|c|c|c|}
\hline Wavenumber $\left(\mathrm{cm}^{-1}\right)$ & Assigned Biochemical Component & Vibrational Mode \\
\hline 3277 & Amide A: peptide, protein & N-H stretching \\
\hline 3053 & Amide B: peptide, protein & $\mathrm{N}-\mathrm{H}$ stretching \\
\hline 2948 & \multirow{3}{*}{ Lipids } & $\mathrm{CH}_{3}$ asymmetric stretching \\
\hline 2920 & & $\mathrm{CH}_{2}$ asymmetric stretching \\
\hline 2860 & & $\mathrm{CH}_{2}$ symmetric stretching \\
\hline 1742 & Phospholipid esters & $\mathrm{C}=\mathrm{O}$ stretching \\
\hline 1639 & Amide I: parallel $\beta$-sheets & $\begin{array}{l}\mathrm{C}=\mathrm{O} \text { stretching, C-N } \\
\text { stretching, in-plane } \\
\mathrm{N}-\mathrm{H} \text { bending }\end{array}$ \\
\hline 1532 & Amide II & $\begin{array}{l}\text { N-H stretching, C-N } \\
\text { stretching, C-C stretching }\end{array}$ \\
\hline 1444 & Membrane lipids and proteins & $\mathrm{CH}_{3}$ and $\mathrm{CH}_{2}$ deformation \\
\hline 1388 & Phospholipid, fatty acid, triglyceride & $\mathrm{CH}_{3}$ symmetric wagging \\
\hline 1291 & Amide III & $\begin{array}{c}\mathrm{N}-\mathrm{H} \text { bending, } \mathrm{C}-\mathrm{N} \text { stretching, } \\
\mathrm{C}=\mathrm{O} \text { stretching, } \mathrm{C}-\mathrm{C} \\
\text { stretching, } \mathrm{CH}_{3} \text { stretching }\end{array}$ \\
\hline 1232 & Nucleic acids & $\mathrm{PO}_{2}$ - symmetric stretching \\
\hline 1161 & Carbohydrates & C-O stretching \\
\hline 1093 and 1067 & $\begin{array}{l}\text { DNA, RNA, phospholipid, } \\
\text { phosphorylated protein }\end{array}$ & $\mathrm{PO}_{2}$ - symmetric stretching \\
\hline 920 & $\begin{array}{c}\text { Dianionic phosphate monoesters of } \\
\text { phosphorylated proteins and } \\
\text { nucleic acids }\end{array}$ & $\mathrm{PO}_{3}{ }^{2-}$ symmetric stretching \\
\hline
\end{tabular}

FTIR spectroscopy is widely used nowadays in the most diverse scientific areas and much emphasis has been given to the application of this technique as a possible method of early diagnosis of cancer. Many promising results have been demonstrated, since this spectroscopic technique appears to be a better approach compared to traditional diagnostic methods (histochemical methods), which are more expensive and more time consuming. Although, by itself it constitutes a technique with a great potential for diagnosis, in order to extract biological information from the data, it is necessary to have a greater knowledge of the spectroscopic characteristics of the different nodular lesions, both benign and malignant, and, simultaneously, the development of complementary statistical methods that allow to differentiate with greater sensitivity and specificity the different samples analyzed corresponding to these pathologies $[62,67,68,72]$. It is unquestionable that the quality and relevance of the information collected through spectral analysis and the potential application of the information collected in clinical practice, such as diagnosis and prognosis, is only possible using multivariate analysis tools. Additional information about these tools and their application in data analysis can be found in [94-96].

As previously mentioned, in order to improve the prognosis of patients who present thyroid carcinomas, and taking into account that the majority of these nodular thyroid lesions are receptive to medical and surgical management, it is important to use diagnostic methods that allow their early detection; FTIR spectroscopy seems to be an excellent option to be applied in this context [47]. The available thyroid cancer studies discriminate and characterize both healthy and pathological thyroid samples and the analysis is performed in tissue anatomic pieces obtained after thyroidectomy [61,66-70,72-79], in cytological samples obtained from the realization of FNA biopsies $[62,72,75]$ or even through the 
application of the FTIR spectroscopy technique in a non-invasive way; that is, applied to the skin surface on thyroid nodules [63-65,71].

According to Table 1, one of the first studies carried out involving the FTIR spectroscopy technique in the diagnosis of thyroid neoplasms showed the presence of thyroglobulin, collagen fibers and some bands related to unknown proteins in the analyzed samples. This study allowed to conclude that although a minor overlap between the bivariate analysis histograms of neoplastic tissues and normal tissues exists, this technique can efficiently allow the distinction between cancer cells and normal cells of the thyroid gland [75]. Integrating the information from tables 1 and 2, this distinction and therefore the confirmation of the malignancy, of certain thyroid samples was also observed in other studies, in which the FTIR spectra of nodular goiter (NG) tissue and the papillary thyroid cancer (PTC) were compared, and significant differences in proteins $\left(1700-1500 \mathrm{~cm}^{-1}\right)$, lipids $\left(4000-2500 \mathrm{~cm}^{-1}\right.$ and $\left.1700 \mathrm{~cm}^{-1}\right)$ and nucleic acids $\left(1200-600 \mathrm{~cm}^{-1}\right)$ were found $[63,68]$. However, there is still a study that, despite showing significant differences between the spectra of the NG and thyroid carcinoma groups, similarly to previous studies, in practically all regions of the spectrum demonstrates the inexistence of these differences in the protein region (amide I and amide II signals) [77]. In this process of differentiation between normal, benign and/or malignant thyroid samples, there are studies that show the great importance of DNA and of some small metabolic products, as DNA metabolism is increased in tumor samples, as verified, although sometimes with less significance, with proteins $[62,67,69,79]$. Accordingly, there are several studies that also show an alteration in lipid metabolism in tumor thyroid tissues, due to the increased consumption of lipids (differences observed in 4000-2500 $\mathrm{cm}^{-1}$ and $1700 \mathrm{~cm}^{-1}$ ), as well as carbohydrates (differences observed in fingerprint region: $1500-600 \mathrm{~cm}^{-1}$ ), by these malignant tissues, thus resulting in a decreased absorbance when comparing malignant thyroid samples with the normal ones in the regions corresponding to these biomolecules $[63,67,70,79]$. Another aspect presented in different studies that allow the distinction between cancerous and normal thyroid samples is related to the protein secondary structure evidenced. The existence of a $\beta$-sheet structure in cancerous samples has been demonstrated, while normal samples show an $\alpha$-helix structure, these structural differences can be evaluated thought the location of the spectroscopic signal around $1600 \mathrm{~cm}^{-1}$ [61,79]. Although FTIR can be used to analyze plasma for metabolic and spectroscopic profiling there are no studies using the plasma of nodular thyroid pathologies patients.

\section{Conclusions}

Thyroid nodular disease is one of the most recurrent endocrine disorders worldwide, and in recent decades its incidence and prevalence have increased considerably. Although only a minority of these lesions present a malignant character, it is crucial to carry out an early diagnosis. One of the very simple and fast diagnostic techniques, even considered the gold standard technique in this process, is the FNA biopsy technique. Despite its routine clinical applicability, this technique is quite often associated with diagnostic errors that result from inconclusive, indeterminate and false-positive cytological results. To counteract the high percentage of thyroids removed unnecessarily due to misdiagnosis, the application of metabolomic techniques in the diagnosis of thyroid nodules seems to be a promising alternative. By allowing the study of all biomolecules that make up the sample under analysis, any metabolomic alteration that may occur is likely to be detected, which could result in the consequent identification of possible early biomarkers for the diagnosis of thyroid cancer. The FTIR spectroscopy technique is one of the metabolomic methods that has shown to be very promising with regard to the diagnosis of various types of cancer, including of the thyroid gland. Characteristics such as its simplicity, speed, objectivity, non-invasiveness, lack of use of reagents, little need for preparation and the small amount of sample needed make this technique an excellent option to be routinely applied in clinical diagnosis in the future. Since this innovative technique allows the screening of the metabolic profile of the analyzed samples and, consequently, allows to 
trace the spectroscopic profile of each of these samples, it may be possible, through its application, to categorize a vast number of analyzed samples in different types of thyroid nodules according to their spectroscopic signatures. In order for this methodology to be tested and validated for its effectiveness, it is necessary to create different cohorts representing the different types of thyroid nodules under analysis. Although it is essential to carry out further studies for its clinical application, FTIR spectroscopy promises to be a very helpful method in the area of thyroid cancer diagnosis.

Funding: This study was developed within the scope of the Institute of Biomedicine-iBiMED (UIDB/04501/2020 and POCI-01-0145-FEDER-007628), financially supported by the Portuguese Foundation for Science and Technology (FCT), Compete2020 and FEDER, and by the project MEDISIS Promotion and involvement of the Central Region key actors for the transfer of knowledge and creation of new partnerships in the areas of Systems Medicine financially supported by Centro2020 (FEDER) and PT2020 (CENTRO-01-0246-FEDER-000018).

Conflicts of Interest: The authors declare no conflict of interest.

\section{References}

1. Nguyen, Q.T.; Lee, E.J.; Huang, M.G.; Park, Y.I.; Khullar, A.; Plodkowski, R.A. Diagnosis and treatment of patients with thyroid cancer. Am. Health Drug Benefits 2015, 8, 30-40.

2. Bailey, S.; Wallwork, B. Differentiating between benign and malignant thyroid nodules. Aust. J. Gen. Pract. 2018, 47, 770-774. [CrossRef]

3. Chen, D.; Hu, J.; Zhu, M.; Tang, N.; Yang, Y.; Feng, Y. Diagnosis of thyroid nodules for ultrasonographic characteristics indicative of malignancy using random forest. BioData Min. 2020, 13, 1-21. [CrossRef]

4. Institute for Quality and Efficiency in Health Care, How Does the Thyroid Gland Work? Institute for Quality and Efficiency in Health Care (IQWiG): Köln, Germany, 2018.

5. Gardner, D.G.; Shoback, D. Greenspan's Basic \& Clinical Endocrinology, 9th ed.; McGraw Hill Education: New York, NY, USA, 2011.

6. Geetha, K.; Baboo, C.S.S. An Empirical Model for Thyroid Disease Classification using Evolutionary Multivariate Bayseian Prediction Method. Glob. J. Comput. Sci. Technol. E Netw. Web Secur. 2016, 16, 1-10.

7. Mounika, B.; Brahmaiah, B.; Ramesh, R.; Bravaneswari, K.; Lakshmi, T.A.; Nama, S. Review on thyroid disorders. Int. J. Pharm. Res. Bio-Sci. 2013, 2, 197-214.

8. Cooper, D.S.; Doherty, G.M.; Haugen, B.R.; Kloos, R.T.; Lee, S.L.; Mandel, S.J.; Mazzaferri, E.L.; McIver, B.; Pacini, F.; Schlumberger, M.; et al. Revised American thyroid association management guidelines for patients with thyroid nodules and differentiated thyroid cancer. Thyroid 2009, 19, 1167-1214. [CrossRef] [PubMed]

9. Durante, C.; Costante, G.; Lucisano, G.; Bruno, R.; Meringolo, D.; Paciaroni, A.; Puxeddu, E.; Torlontano, M.; Tumino, S.; Attard, M.; et al. The natural history of benign thyroid nodules. JAMA-J. Am. Med. Assoc. 2015, 313, 926-935. [CrossRef]

10. Kwong, N.; Medici, M.; Angell, T.E.; Liu, X.; Marqusee, E.; Cibas, E.S.; Krane, J.F.; Barletta, J.A.; Kim, M.I.; Larsen, P.R.; et al. The influence of patient age on thyroid nodule formation, multinodularity, and thyroid cancer risk. J. Clin. Endocrinol. Metab. 2015, 100, 4434-4440. [CrossRef]

11. Guth, S.; Theune, U.; Aberle, J.; Galach, A.; Bamberger, C.M. Very high prevalence of thyroid nodules detected by high frequency (13 MHz) ultrasound examination. Eur. J. Clin. Investg. 2009, 39, 699-706. [CrossRef]

12. Durante, C.; Grani, G.; Lamartina, L.; Filetti, S.; Mandel, S.J.; Cooper, D.S. The diagnosis and management of thyroid nodules a review. JAMA-J. Am. Med. Assoc. 2018, 319, 919-924. [CrossRef] [PubMed]

13. Choi, J.S.; Nam, C.M.; Kim, E.K.; Moon, H.J.; Han, K.H.; Kwak, J.Y. Evaluation of serum thyroid-stimulating hormone as indicator for fine-needle aspiration in patients with thyroid nodules. Head Neck 2015, 37, 498-504. [CrossRef]

14. Xu, W.; Huo, L.; Chen, Z.; Huang, Y.; Jin, X.; Deng, J.; Zhu, S.; Yu, Y. The relationship of TPOab and TGAb with risk of thyroid nodules: A large epidemiological study. Int. J. Environ. Res. Public Health 2017, 14, 723. [CrossRef]

15. Panagiotou, G.; Komninou, D.; Anagnostis, P.; Linardos, G.; Karoglou, E.; Somali, M.; Duntas, L.; Kita, M.; Tziomalos, K.; Pazaitou-Panayiotou, K. Association between lifestyle and anthropometric parameters and thyroid nodule features. Endocrine 2017, 56, 560-567. [CrossRef]

16. Shin, J.; Kim, M.H.; Yoon, K.H.; Kang, M.-I.; Cha, B.Y.; Lim, D.J. Relationship between metabolic syndrome and thyroid nodules in healthy Koreans. Korean J. Intern. Med. 2016, 31, 98-105. [CrossRef]

17. Haugen, B.R.; Alexander, E.K.; Bible, K.C.; Doherty, G.M.; Mandel, S.J.; Nikiforov, Y.E.; Pacini, F.; Randolph, G.W.; Sawka, A.M.; Schlumberger, M.; et al. 2015 American Thyroid Association Management Guidelines for Adult Patients with Thyroid Nodules and Differentiated Thyroid Cancer: The American Thyroid Association Guidelines Task Force on Thyroid Nodules and Differentiated Thyroid Cancer. Thyroid 2016, 26, 1-133. [CrossRef] [PubMed]

18. Kumar, V.; Abbas, A.K.; Aster, J.C. Robbins Basic Pathology, 10th ed.; Elsevier-Health Sciences Division, Ed.; Elsevier: Amsterdam, The Netherlands, 2017.

19. Popoveniuc, G.; Jonklaas, J. Thyroid Nodules. Med. Clin. North Am. 2012, 96, 329-349. [CrossRef] 
20. Erdogan, M.F.; Gursoy, A.; Erdogan, G. Natural course of benign thyroid nodules in a moderately iodine-deficient area. Clin. Endocrinol. 2006, 65, 767-771. [CrossRef]

21. Bible, K.C.; Kebebew, E.; Brierley, J.; Brito, J.P.; Cabanillas, M.E.; Clark, T.J.; Di Cristofano, A.; Foote, R.; Giordano, T.; Kasperbauer, J.; et al. 2021 American Thyroid Association Guidelines for Management of Patients with Anaplastic Thyroid Cancer. Thyroid 2021, 31, 337-386. [CrossRef] [PubMed]

22. Cabanillas, M.E.; McFadden, D.G.; Durante, C. Thyroid cancer. Lancet 2016, 388, 2783-2795. [CrossRef]

23. Papaleontiou, M.; Hughes, D.T.; Guo, C.; Banerjee, M.; Haymart, M.R. Population-based assessment of complications following surgery for thyroid cancer. J. Clin. Endocrinol. Metab. 2017, 102, 2543-2551. [CrossRef] [PubMed]

24. Filho, J.G.; Kowalski, L.P. Postoperative complications of thyroidectomy for differentiated thyroid carcinoma. Am. J. Otolaryngol.-Head Neck Med. Surg. 2004, 25, 225-230. [CrossRef] [PubMed]

25. Verloop, H.; Louwerens, M.; Schoones, J.W.; Kievit, J.; Smit, J.W.A.; Dekkers, O.M. Risk of hypothyroidism following hemithyroidectomy: Systematic review and meta-analysis of prognostic studies. J. Clin. Endocrinol. Metab. 2012, 97, 2243-2255. [CrossRef]

26. McCaffrey, T.V.; Bergstralh, E.J.; Hay, I.D. Locally invasive papillary thyroid carcinoma: 1940-1990. Head Neck 1994, 16, 165-172. [CrossRef] [PubMed]

27. Adair, C. Non-Neoplastic Lesions of the Thyroid Gland. In Head and Neck Pathology; Thompson, L.D.R., Goldblum, J.R., Eds.; Elsevier: Amsterdam, The Netherlands, 2019; pp. 498-545.

28. Lloyd, R.V.; Osamura, Y.R.; Kloppel, G.; Rosai, J. WHO Classification of Tumours of Endocrine Organs, 4th ed.; Lloyd, R.V., Osamura, R.Y., Klöppel, G., Rosai, J., Eds.; International Agency for Research on Cancer (IARC): Lyon, France, 2017.

29. Benbassat, C.A.; Mechlis-Frish, S.; Hirsch, D. Clinicopathological characteristics and long-term outcome in patients with distant metastases from differentiated thyroid cancer. World J. Surg. 2006, 30, 1088-1095. [CrossRef]

30. National Cancer Institute. Thyroid Cancer-Cancer Stat Facts. Available online: https://seer.cancer.gov/statfacts/html/thyro. html?fbclid=IwAR0dkaKUSnRAXHiJSiZV6lzmVO3nijA1Y1pSjYDeMzqLjFkGoqBhZEu9QaM (accessed on 25 November 2021).

31. Davies, L.; Welch, H.G. Current thyroid cancer trends in the United States. JAMA Otolaryngol.-Head Neck Surg. 2014, 140, 317-322. [CrossRef] [PubMed]

32. Davies, L.; Welch, H.G. Increasing incidence of thyroid cancer in the United States, 1973-2002. J. Am. Med. Assoc. 2006, 295, 2164-2167. [CrossRef]

33. Colonna, M.; Guizard, A.V.; Schvartz, C.; Velten, M.; Raverdy, N.; Molinie, F.; Delafosse, P.; Franc, B.; Grosclaude, P. A time trend analysis of papillary and follicular cancers as a function of tumour size: A study of data from six cancer registries in France (1983-2000). Eur. J. Cancer 2007, 43, 891-900. [CrossRef]

34. Roti, E.; Rossi, R.; Trasforini, G.; Bertelli, F.; Ambrosio, M.R.; Busutti, L.; Pearce, E.N.; Braverman, L.E.; Degli Uberti, E.C. Clinical and histological characteristics of papillary thyroid microcarcinoma: Results of a retrospective study in 243 patients. $J$. Clin. Endocrinol. Metab. 2006, 91, 2171-2178. [CrossRef] [PubMed]

35. Li, M.; Maso, L.D.; Vaccarella, S. Global trends in thyroid cancer incidence and the impact of overdiagnosis. Lancet Diabetes Endocrinol. 2020, 8, 468-470. [CrossRef]

36. Hedman, C.; Strang, P.; Djärv, T.; Widberg, I.; Lundgren, C.I. Anxiety and Fear of Recurrence Despite a Good Prognosis: An Interview Study with Differentiated Thyroid Cancer Patients. Thyroid 2017, 27, 1417-1423. [CrossRef] [PubMed]

37. Tamhane, S.; Gharib, H. Thyroid nodule update on diagnosis and management. Clin. Diabetes Endocrinol. 2016, 2, 1-10. [CrossRef]

38. Russ, G.; Bonnema, S.J.; Erdogan, M.F.; Durante, C.; Ngu, R.; Leenhardt, L. European Thyroid Association Guidelines for Ultrasound Malignancy Risk Stratification of Thyroid Nodules in Adults: The EU-TIRADS. Eur. Thyroid J. 2017, 6, 225-237. [CrossRef] [PubMed]

39. Tessler, F.N.; Middleton, W.D.; Grant, E.G.; Hoang, J.K.; Berland, L.L.; Teefey, S.A.; Cronan, J.J.; Beland, M.D.; Desser, T.S.; Frates, M.C.; et al. ACR Thyroid Imaging, Reporting and Data System (TI-RADS): White Paper of the ACR TI-RADS Committee. J. Am. Coll. Radiol. 2017, 14, 587-595. [CrossRef] [PubMed]

40. Paschke, R.; Cantara, S.; Crescenzi, A.; Jarzab, B.; Musholt, T.J.; Sobrinho Simoes, M. European Thyroid Association Guidelines regarding Thyroid Nodule Molecular Fine-Needle Aspiration Cytology Diagnostics. Eur. Thyroid J. 2017, 6, 115-129. [CrossRef] [PubMed]

41. Wang, C.C.C.; Friedman, L.; Kennedy, G.C.; Wang, H.; Kebebew, E.; Steward, D.L.; Zeiger, M.A.; Westra, W.H.; Wang, Y.; Khanafshar, E.; et al. A large multicenter correlation study of thyroid nodule cytopathology and histopathology. Thyroid 2011, 21, 243-251. [CrossRef]

42. Navas-Carrillo, D.; Rodriguez, J.M.; Montoro-García, S.; Orenes-Piñero, E. High-resolution proteomics and metabolomics in thyroid cancer: Deciphering novel biomarkers. Crit. Rev. Clin. Lab. Sci. 2017, 54, 446-457. [CrossRef]

43. Wojakowska, A.; Chekan, M.; Widlak, P.; Pietrowska, M. Application of metabolomics in thyroid cancer research. Int. J. Endocrinol. 2015, 2015, 1-13. [CrossRef]

44. Abooshahab, R.; Gholami, M.; Sanoie, M.; Azizi, F.; Hedayati, M. Advances in metabolomics of thyroid cancer diagnosis and metabolic regulation. Endocrine 2019, 65, 1-14. [CrossRef]

45. Sussulini, A. Erratum to: Chapters 1 and 11 of Metabolomics: From Fundamentals to Clinical Applications. Adv. Exp. Med. Biol. 2017, 965, E1-E2. [CrossRef]

46. Rocha, A.; Magalhães, S.; Nunes, A. Cell Culture Studies: A Promising Approach to the Metabolomic Study of Human Aging. Curr. Metab. Syst. Biol. 2021, 8, 1-26. [CrossRef] 
47. Ellis, D.I.; Dunn, W.B.; Griffin, J.L.; Allwood, J.W.; Goodacre, R. Metabolic fingerprinting as a diagnostic tool. Pharmacogenomics 2007, 8, 1243-1266. [CrossRef]

48. Singh, A.; Ham, J.; Po, J.W.; Niles, N.; Roberts, T.; Lee, C.S. The Genomic Landscape of Thyroid Cancer Tumourigenesis and Implications for Immunotherapy. Cells 2021, 10, 1082. [CrossRef]

49. Yoo, S.K.; Song, Y.S.; Lee, E.K.; Hwang, J.; Kim, H.H.; Jung, G.; Kim, Y.A.; Kim, S.J.; Cho, S.W.; Won, J.K.; et al. Integrative analysis of genomic and transcriptomic characteristics associated with progression of aggressive thyroid cancer. Nat. Commun. 2019, 10, 1-12. [CrossRef] [PubMed]

50. García-Vence, M.; Chantada-Vázquez, M.D.P.; Cameselle-Teijeiro, J.M.; Bravo, S.B.; Núñez, C. A Novel Nanoproteomic Approach for the Identification of Molecular Targets Associated with Thyroid Tumors. Nanomaterials 2020, 10, 2370. [CrossRef] [PubMed]

51. Dai, J.; Yu, X.; Han, Y.; Chai, L.; Liao, Y.; Zhong, P.; Xie, R.; Sun, X.; Huang, Q.; Wang, J.; et al. TMT-labeling proteomics of papillary thyroid carcinoma reveal invasive biomarkers. J. Cancer 2020, 11, 6122-6132. [CrossRef]

52. Pu, W.; Shi, X.; Yu, P.; Zhang, M.; Liu, Z.; Tan, L.; Han, P.; Wang, Y.; Ji, D.; Gan, H.; et al. Single-cell transcriptomic analysis of the tumor ecosystems underlying initiation and progression of papillary thyroid carcinoma. Nat. Commun. 2021, 12, 1-18. [CrossRef]

53. Coelho, M.; Raposo, L.; Goodfellow, B.J.; Atzori, L.; Jones, J.; Manadas, B. The potential of metabolomics in the diagnosis of thyroid cancer. Int. J. Mol. Sci. 2020, 21, 5272. [CrossRef] [PubMed]

54. Du, Y.; Fan, P.; Zou, L.; Jiang, Y.; Gu, X.; Yu, J.; Zhang, C. Serum Metabolomics Study of Papillary Thyroid Carcinoma Based on HPLC-Q-TOF-MS/MS. Front. Cell Dev. Biol. 2021, 9, 1-13. [CrossRef] [PubMed]

55. Abooshahab, R.; Hooshmand, K.; Razavi, S.A.; Gholami, M.; Sanoie, M.; Hedayati, M. Plasma Metabolic Profiling of Human Thyroid Nodules by Gas Chromatography-Mass Spectrometry (GC-MS)-Based Untargeted Metabolomics. Front. Cell Dev. Biol. 2020, 8, 1-13. [CrossRef]

56. Rezig, L.; Servadio, A.; Torregrossa, L.; Miccoli, P.; Basolo, F.; Shintu, L.; Caldarelli, S. Diagnosis of post-surgical fine-needle aspiration biopsies of thyroid lesions with indeterminate cytology using HRMAS NMR-based metabolomics. Metabolomics 2018, 14, 1-10. [CrossRef]

57. Wang, T.; Sun, Z.; Wang, Y.; Li, F.; Zhou, X.; Tian, X.; Wang, S. Diagnosis of papillary thyroid carcinoma by $1 \mathrm{H}$ NMR spectroscopybased metabolomic analysis of whole blood. Drug Discov. Ther. 2020, 14, 187-196. [CrossRef]

58. Sbroscia, M.; Di Gioacchino, M.; Ascenzi, P.; Crucitti, P.; di Masi, A.; Giovannoni, I.; Longo, F.; Mariotti, D.; Naciu, A.M.; Palermo, A.; et al. Thyroid cancer diagnosis by Raman spectroscopy. Sci. Rep. 2020, 10, 1-10. [CrossRef]

59. Liang, X.; Miao, X.; Xiao, W.; Ye, Q.; Wang, S.; Lin, J.; Li, C.; Huang, Z. Filter-membrane-based ultrafiltration coupled with surface-enhanced raman spectroscopy for potential differentiation of benign and malignant thyroid tumors from blood plasma. Int. J. Nanomed. 2020, 15, 2303-2314. [CrossRef]

60. O’Dea, D.; Bongiovanni, M.; Sykiotis, G.P.; Ziros, P.G.; Meade, A.D.; Lyng, F.M.; Malkin, A. Raman spectroscopy for the preoperative diagnosis of thyroid cancer and its subtypes: An in vitro proof-of-concept study. Cytopathology 2019, 30, 51-60. [CrossRef] [PubMed]

61. Depciuch, J.; Stanek-Widera, A.; Skrzypiec, D.; Lange, D.; Biskup-Frużyńska, M.; Kiper, K.; Stanek-Tarkowska, J.; Kula, M.; Cebulski, J. Spectroscopic identification of benign (follicular adenoma) and cancerous lesions (follicular thyroid carcinoma) in thyroid tissues. J. Pharm. Biomed. Anal. 2019, 170, 321-326. [CrossRef] [PubMed]

62. Liu, K.Z.; Schultz, C.P.; Salamon, E.A.; Man, A.; Mantsch, H.H. Infrared spectroscopic diagnosis of thyroid tumors. J. Mol. Struct. 2003, 661-662, 397-404. [CrossRef]

63. Zhang, W.; Tian, P.; Zhu, Q.; Zhang, Y.; Cui, L.; Xu, Z. Noninvasive surface detection of papillary thyroid carcinoma by Fourier transform infrared spectroscopy. Chem. Res. Chin.Univ. 2015, 31, 198-202. [CrossRef]

64. Liu, Y.-Q.; Xu, Y.-Z.; Sun, Q.-G.; Zhang, X.-Q.; Xu, Z.; Zhang, Y.-F.; Wu, J.-G.; Zhou, X.-S.; Ling, X.-F. [Surface detection of thyroid cancer by Fourier transform infrared spectroscopy]. Zhonghua Zhong Liu Za Zhi 2009, 31, 908-910.

65. Ling, X.F.; Xu, Z.; Xu, Y.Z.; Zhou, S.; Zhang, N.W.; Wang, L.X.; Hou, C.S.; Zhang, Y.F.; Zhou, X.S.; Wu, J.G. Nodular goiter surface detection by FTIR spectroscopy. Guang Pu Xue Yu Guang Pu Fen Xi 2005, 25, 1955-1958.

66. Liu, Y.Q.; Gao, M.J.; Xu, Y.Z.; Sun, Q.G.; Zhang, X.Q.; Xu, Z.; Zhang, Y.F.; Wu, J.G.; Zhou, X.S.; Ling, X.F. Investigation on fourier transform infrared spectrum of metastatic lymph node in thyroid cancer. Guang Pu Xue Yu Guang Pu Fen Xi 2009, 29, 2917-2921. [CrossRef]

67. Liu, Y.; Xu, Y.; Liu, Y.; Zhang, Y.; Wang, D.; Xiu, D.; Xu, Z.; Zhou, X.; Wu, J.; Ling, X. Detection of cervical metastatic lymph nodes in papillary thyroid carcinoma by Fourier transform infrared spectroscopy. Br. J. Surg. 2011, 98, 380-384. [CrossRef]

68. Zhang, X.; Xu, Y.; Zhang, Y.; Wang, L.; Hou, C.; Zhou, X.; Ling, X.; Xu, Z. Intraoperative detection of thyroid carcinoma by fourier transform infrared spectrometry. J. Surg. Res. 2011, 171, 650-656. [CrossRef]

69. da Silva, R.M.; Pupin, B.; Bhattacharjee, T.T.; Vamondes Kulcsar, M.A.; Uno, M.; Chammas, R.; de Azevedo Canevari, R. ATR-FTIR spectroscopy and CDKN1C gene expression in the prediction of lymph nodes metastases in papillary thyroid carcinoma. Spectrochim. Acta. A Mol. Biomol. Spectrosc. 2020, 228, 1-22. [CrossRef]

70. Santillan, A.; Tomas, R.C.; Bangaoil, R.; Lopez, R.; Gomez, M.H.; Fellizar, A.; Lim, A.; Abanilla, L.; Ramos, M.C.; Guevarra, L.; et al Discrimination of malignant from benign thyroid lesions through neural networks using FTIR signals obtained from tissues. Anal. Bioanal. Chem. 2021, 413, 2163-2180. [CrossRef] [PubMed]

71. Wu, M.; Zhang, W.T.; Tian, P.R.; Ling, X.F.; Xu, Z. Characteristics analysis of the thyroid gland surface of normal human with Fourier transform infrared (FTIR) spectra. Guang Pu Xue Yu Guang Pu Fen Xi 2016, 36, 3092-3096. [CrossRef] 
72. Albero, F.G. Diagnóstico de Lesões da Tireóide Pela Espectroscopia de Absorção no Infravermelho por Transformada de Fourier-FTIR; Biblioteca Digital de Teses e Dissertações da Universidade de São Paulo: São Paulo, Brazil, 2009.

73. Pereira, T.M.; Zezell, D.M.; Bird, B.; Miljković, M.; Diem, M. The characterization of normal thyroid tissue by micro-FTIR spectroscopy. Analyst 2013, 138, 7094-7100. [CrossRef]

74. Zeng, X.T.; Xu, Y.Z.; Zhang, X.Q.; Xu, Z.; Zhang, Y.F.; Wu, J.G.; Zhou, X.S.; Ling, X.F. FTIR spectroscopic explorations of freshly resected thyroid malignant tissues. Guang Pu Xue Yu Guang Pu Fen Xi 2007, 27, 2422-2426. [PubMed]

75. Schultz, C.P.; Liu, K.Z.; Salamon, E.A.; Riese, K.T.; Mantsch, H.H. Application of FT-IR microspectroscopy in diagnosing thyroid neoplasms. J. Mol. Struct. 1999, 480-481, 369-377. [CrossRef]

76. Martinez-Marin, D.; Sreedhar, H.; Varma, V.K.; Eloy, C.; Sobrinho-Simões, M.; Kajdacsy-Balla, A.; Walsh, M.J. Accounting for tissue heterogeneity in infrared spectroscopic imaging for accurate diagnosis of thyroid carcinoma subtypes. Vib. Spectrosc. 2017, 91, 77-82. [CrossRef]

77. Wu, M.; Zhang, W.; Tian, P.; Ling, X.; Xu, Z. Intraoperative diagnosis of thyroid diseases by fourier transform infrared spectroscopy based on support vector machine. Int. J. Clin. Exp. Med. 2016, 9, 2351-2358.

78. Villela, L.F.d.A.; de Freitas, L.C.C.; Brandão, M.; Bachmann, L.; Iwakura, R. Characterization of thyroid tissue using infrared spectroscopy. Arch. Head Neck Surg. 2018, 47, 1-10. [CrossRef]

79. Depciuch, J.; Stanek-Widera, A.; Lange, D.; Biskup-Frużyńska, M.; Stanek-Tarkowska, J.; Czarny, W.; Cebulski, J. Spectroscopic analysis of normal and neoplastic (WI-FTC) thyroid tissue. Spectrochim. Acta A Mol. Biomol. Spectrosc. 2018, 204, 18-24. [CrossRef] [PubMed]

80. Minuto, M.N.; Shintu, L.; Caldarelli, S. Proteomics, and Metabolomics: Magnetic Resonance Spectroscopy for the Presurgical Screening of Thyroid Nodules. Curr. Genom. 2014, 15, 178-183. [CrossRef] [PubMed]

81. Gupta, N.; Goswami, B.; Chowdhury, V.; RaviShankar, L.; Kakar, A. Evaluation of the role of magnetic resonance spectroscopy in the diagnosis of follicular malignancies of thyroid. Arch. Surg. 2011, 146, 179-182. [CrossRef] [PubMed]

82. Kaplan, M.M. Clinical perspectives in the diagnosis of thyroid disease. Clin. Chem. 1999, 45, 1377-1383. [CrossRef] [PubMed]

83. Nunes, A. FTIR Spectroscopy-A Potential Tool to Identify Metabolic Changes in Dementia Patients. HSOA J. Alzheimers Neurodegener. Dis. 2016, 2, 1-9. [CrossRef]

84. Bellisola, G.; Sorio, C. Infrared spectroscopy and microscopy in cancer research and diagnosis. Am. J. Cancer Res. $2012,2,1-21$.

85. Kaznowska, E.; Depciuch, J.; Łach, K.; Kołodziej, M.; Koziorowska, A.; Vongsvivut, J.; Zawlik, I.; Cholewa, M.; Cebulski, J. The classification of lung cancers and their degree of malignancy by FTIR, PCA-LDA analysis, and a physics-based computational model. Talanta 2018, 186, 337-345. [CrossRef]

86. Lu, Y.; Zhao, Y.; Zhu, Y.; Xu, X.; Yin, J. In situ research and diagnosis of breast cancer by using HOF-ATR-FTIR spectroscopy. Spectrochim. Acta A Mol. Biomol. Spectrosc. 2020, 235, 1-17. [CrossRef]

87. Felgueiras, J.; Vieira Silva, J.; Nunes, A.; Patrício, A.; Pelech, S.; Fardilha, M. Understanding prostate cancer biology using metabolomics and proteomics approaches: Potentials in the improvement of the diagnosis, prognosis and identification of new therapeutic targets. Eur. J. Cancer 2017, 72, S192. [CrossRef]

88. Santos, F.; Magalhães, S.; Henriques, M.C.; Silva, B.; Valença, I.; Ribeiro, D.; Fardilha, M.; Nunes, A. Understanding Prostate Cancer Cells Metabolome: A Spectroscopic Approach. Curr. Metab. 2018, 6, 218-224. [CrossRef]

89. Thumanu, K.; Sangrajrang, S.; Khuhaprema, T.; Kalalak, A.; Tanthanuch, W.; Pongpiachan, S.; Heraud, P. Diagnosis of liver cancer from blood sera using FTIR microspectroscopy: A preliminary study. J. Biophotonics 2014, 7, 222-231. [CrossRef] [PubMed]

90. Zelig, U.; Barlev, E.; Bar, O.; Gross, I.; Flomen, F.; Mordechai, S.; Kapelushnik, J.; Nathan, I.; Kashtan, H.; Wasserberg, N.; et al. Early detection of breast cancer using total biochemical analysis of peripheral blood components: A preliminary study. BMC Cancer 2015, 15, 1-10. [CrossRef]

91. Su, K.Y.; Lee, W.L. Fourier transform infrared spectroscopy as a cancer screening and diagnostic tool: A review and prospects. Cancers 2020, 12, 115. [CrossRef] [PubMed]

92. Stuart, B.H. Infrared Spectroscopy of Biological Applications: An Overview. In Encyclopedia of Analytical Chemistry; John Wiley \& Sons, Ltd.: Chichester, UK, 2012; pp. 1-17.

93. Santos, F.; Magalhaes, S.; Henriques, M.C.; Fardilha, M.; Nunes, A. Spectroscopic Features of Cancer Cells: FTIR Spectroscopy as a Tool for Early Diagnosis. Curr. Metab. 2018, 6, 103-111. [CrossRef]

94. Magalhães, S.; Goodfellow, B.J.; Nunes, A. FTIR spectroscopy in biomedical research: How to get the most out of its potential. Appl. Spectrosc. Rev. 2021, 56, 869-907. [CrossRef]

95. Morais, C.L.M.; Lima, K.M.G.; Singh, M.; Martin, F.L. Tutorial: Multivariate classification for vibrational spectroscopy in biological samples. Nat. Protoc. 2020, 15, 2143-2162. [CrossRef]

96. Rudd, T.R.; Mauri, L.; Marinozzi, M.; Stancanelli, E.; Yates, E.A.; Naggi, A.; Guerrini, M. Multivariate analysis applied to complex biological medicines. Faraday Discuss. 2019, 218, 303-316. [CrossRef] 